\title{
New approach to assessing lung tumours in man
}

\author{
KC GATTER,* MS DUNNILL,* J GERDES, $\uparrow$ H STEIN, $\dagger$ DY MASON*
}

From the *Nuffield Department of Pathology, University of Oxford, John Radcliffe Hospital, Oxford, and the $\dagger$ Institute of Pathology, Klinikum Steglitz, Berlin, West Germany

SUMMARY One hundred and four surgically resected lung tumours were labelled in either cryostat $\stackrel{\circ}{\vec{\circ}}$ or freeze dried sections with a monoclonal antibody (Ki67), which reacts with a nuclear antigen $\vec{\omega}$ expressed by proliferating cells. The tumours were categorised semiquantitatively into four prolifer- $\frac{\bar{O}}{\mathrm{O}}$ ative grades, a classification that can be performed rapidly and reproducibly by the pathologist. In keeping with previous cell kinetic studies all small cell carcinomas had high proliferation rates, whereas the carcinoid tumours were in the lowest grade. In contrast, the adenocarcinomas (27 cases) if and squamous cell carcinomas (63 cases) varied widely in their proliferative state, in keeping with $\&$

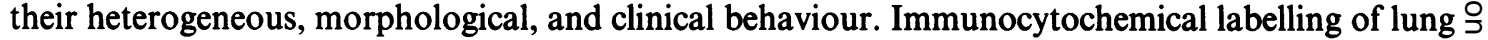
tumour biopsy specimens with antibody $\mathrm{Ki} 67$ is a simple technique within the scope of routine $\vec{c}$ surgical pathology laboratories, which might enable these tumours to be classified according to their proliferative status and treatment to be selected accordingly.

Although morphological classification of lung tumours is complex, several studies have indicated that the crucial distinction from a clinical point of view is between small cell carcinoma and other types of lung cancer. ${ }^{1-3}$ This is based on the premise that small cell carcinoma is a distinct biological entity with a rapidly progressive course and early tumour dissemination. ${ }^{4-6}$ For these reasons it is, in contrast to other lung tumour types, rarely amenable to surgery, but it is sensitive to both radiotherapy and chemotherapy.

It has long been known, however, that tumours of the lung are histologically heterogeneous and that different morphological types may often be seen in the same tumour. ${ }^{7-10}$ Recent studies using electron microscopy and immunocytochemistry have reemphasised this fact. ${ }^{11-18}$ Clinical follow up studies have also consistently shown the unpredictable course of many lung tumours and have begun to question the wisdom of rigidly dividing them into two groups that require totally different strategies of treatment. ${ }^{19-21}$

The recent production of a monoclonal antibody (Ki67), which reacts with a nuclear antigen expressed by proliferating cells, prompted us to use this reagent to assess the growth pattern of a series of tumours in pulmonary resection specimens, using immunocytochemical techniques. ${ }^{223}$ Our aim was to see whether immunohistological assessment of the proliferative activity of lung tumours might show differences between individual neoplasms, which could help the oncologist to make his therapeutic decisions.

Accepted for publication 30 January 1986

\section{Material and methods}

\section{LUNG SPECIMENS}

One hundred and four tumours were received as lung $\bar{\partial}$ resection specimens from the operating theatre. $\mathrm{Re}-\frac{\mathrm{O}}{\mathrm{D}}$ presentative portions of tumour were removed for $\stackrel{\mathbb{Q}}{\varrho}$ snap freezing and storage in liquid nitrogen. During $\overrightarrow{\vec{\sigma}}$ the second half of this study techniques for preparing 3 freeze dried paraffin embedded material became available, and portions of tumour were processed in this way using an Edwards-Pearse ETD4 tissue drier (Edwards High Vacuum, Crawley, United Kingdom), as detailed previously. ${ }^{24} 25$ Additional small samples 3 . from all specimens were fixed immediately in $4 \%$ glutaraldehyde and processed for electron microscopy. $\frac{\mathrm{O}}{3}$ The remainder of the specimen was processed for con- 0 ventional histological examination. The tumours were categorised on light microscopical appearances $\frac{D}{2}$ by two of the authors (KCG and MSD) as either squamous cell carcinoma (63), adenocarcinoma (27), N small (oat) cell carcinoma (5), or carcinoid tumour $\mathrm{N}$ (9).

\section{IMMUNOCYTOCHEMISTRY}

Sections (cryostat or freeze dried, or both) were $\stackrel{0}{E}$

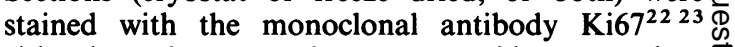
either by a three stage immunoperoxidase procedure ${ }^{+}$ or by the APAAP immunoalkaline phosphatase $\frac{0}{0}$ technique, as detailed previously. ${ }^{2627}$ The antigen $\stackrel{\vec{D}}{\square}$ recognised by Ki67 does not survive conventional $\frac{\rho}{\Phi}$ fixation and is thus not suitable for retrospective $\varrho$ studies on stored paraffin embedded tissue specimens. 


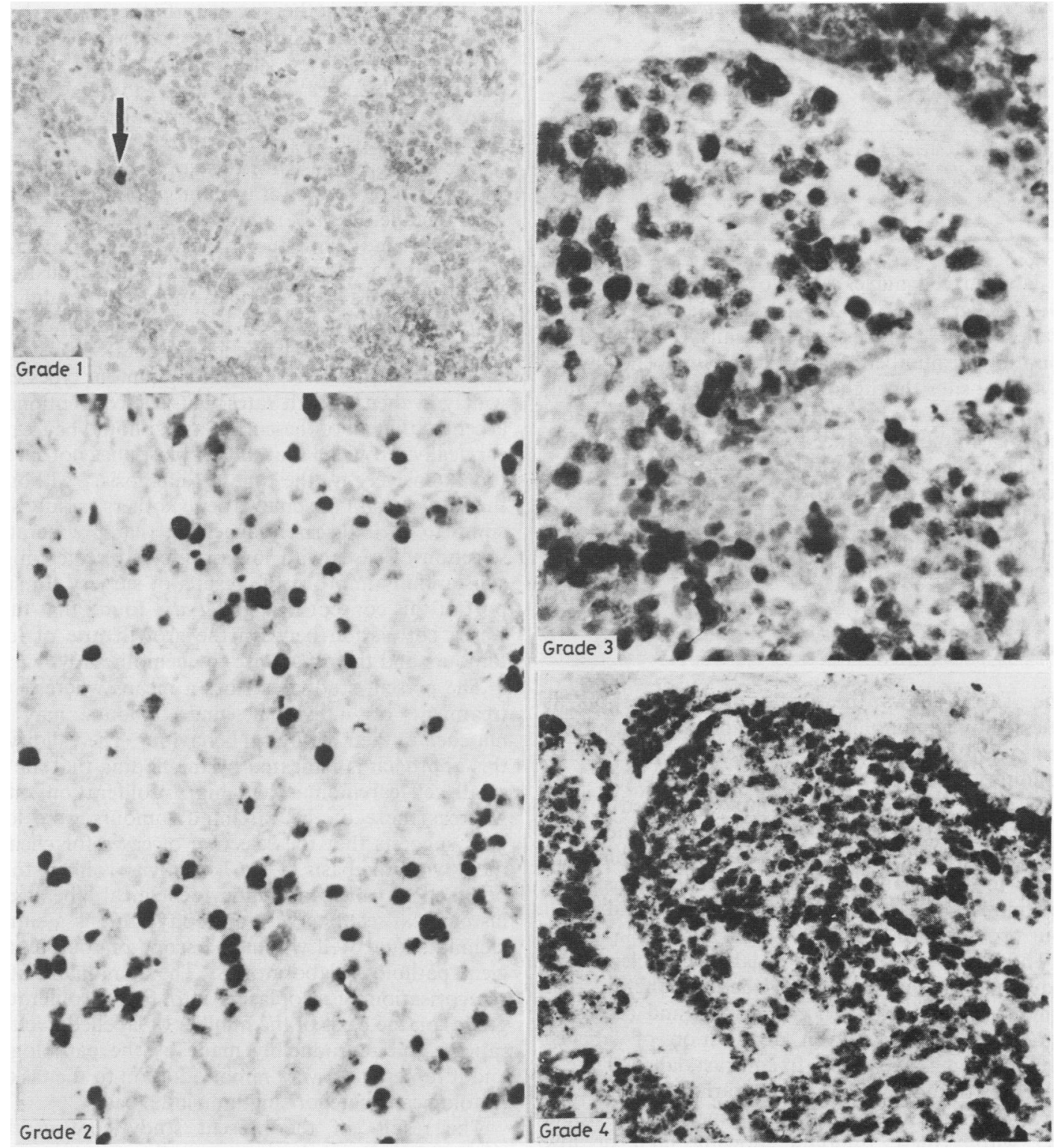

Representative examples of proliferative grading system used in this study. Grade 1 is a carcinoid tumour (single labelled nucleus is arrowed), grades 2 and 3 are squamous cell carcinomas, and grade 4 is an oat cell carcinoma. All sections illustrated were stained by APAAP technique.

\section{PROLIFERATION GRADE}

The monoclonal antibody $\mathrm{Ki} 67$ reacts with a nuclear antigen (as yet unidentified) expressed by cells in all phases of the cycle except $\mathrm{G}_{\mathrm{o}}$. Immunocytochemical labelling with this antibody has been shown to correlate well with conventional measures of cell proliferation using autoradiography and flow cytometry ${ }^{23}$ and therefore provides a reliable means of rapidly evaluating the growth fraction of normal and neoplastic human cell populations. Ki67 is now commercially available (as DAKO-PC) from Dakopatts a/s, Copenhagen.

In the present study the individual tumours were classified into four grades according to the proportion 
Grade of proliferation assessed by immunohistological labelling

\begin{tabular}{lrrrrrr}
\hline \multirow{2}{*}{ Tumour } & \multicolumn{3}{l}{ Grade } & & \multirow{2}{*}{ Total } \\
\cline { 2 - 5 } & \multicolumn{1}{l}{$l$} & 2 & 3 & 4 & \\
\hline Squamous cell carcinoma & 17 & 20 & 20 & 6 & 63 \\
Adenocarcinoma & 14 & 5 & 8 & 0 & 27 \\
Small (oat) cell carcinoma & 0 & 0 & 2 & 3 & 5 \\
Carcinoid & 9 & 0 & 0 & 0 & 9 \\
Total & 40 & 25 & 30 & 9 & 104 \\
\hline
\end{tabular}

of labelled cell nuclei as follows: $0-10 \%$, grade 1 ; $11-25 \%$, grade $2 ; 26-50 \%$, grade 3 ; and $51-75 \%$, grade 4 . These grades were initially established by counting the number of labelled and unlabelled nuclei at several sites throughout the section. It was found, however, that with experience this grading system could easily be reproduced without formal counting simply by visual inspection of the section. This was validated by reviewing all the tumours in this series blindly and comparing this visual estimate with the previously established percentages. Examples of the appearances seen in these four categories are shown in the Figure.

\section{Results}

The Table shows the grade of proliferation as assessed by immunohistological labelling with monoclonal antibody $\mathrm{Ki} 67$ in the series of 104 lung tumours.

All cases of small cell carcinoma showed a high grade of proliferation ( 3 or 4 ), whereas all the carcinoids were in the lowest grade (1). The results were much more variable for the adenocarcinomas and squamous cell carcinomas, which were found in all four proliferation categories.

The distribution patterns of labelled nuclei within individual tumours also varied between the different tumour types. Small cell carcinomas and carcinoid tumours showed an even distribution of labelled nuclei through the section. In contrast, labelled nuclei were distributed much more variably in adenocarcinomas and squamous cell carcinomas, individual foci within these tumours showing high or low numbers of $\mathrm{Ki} 67$ positive nuclei. In such cases the final grading represented an average of the labelled nuclei in all foci. Although this was a semiquantitative estimate, it was reproducible on blind review - that is, tumours were consistently placed within the same proliferation category.

\section{Discussion}

Treatment of lung cancer is currently based on the concept that rapidly growing lesions should be treated with chemotherapy or radiotherapy, or both, while surgery is appropriate for more slowly growing tumours. This view is supported by clinicopathological studies ${ }^{1-3}$ and has led to lung tumours being divided, for therapeutic purposes, into two groups-small cell type and others.

The biological basis for this approach to lung can- $\frac{\overline{\bar{p}}}{\bar{\partial}}$ cer is based on studies of tumour growth rates. These ${ }_{\propto}^{\mathbb{\Phi}}$ have entailed serial radiology, ${ }^{28}$ autoradiography (using tritiated thymidine), or flow cytofluorimetry. ${ }^{29}{ }^{\mathrm{S}}$ Such studies are complex, subject to numerous tech- -9 nical difficulties and artefacts, and are often difficult $\vec{\omega}$ to reproduce. They have, however, confirmed that $\stackrel{\text { S }}{2}$ small cell carcinoma of the lung generally has a high용 proliferation rate. ${ }^{30-32}$ Other lung tumour types vary widely in their growth rates, but it is conventionally of accepted that all of these neoplasms should be treatedir surgically, provided that the neoplasm has not spread $\%$ too extensively by the time of diagnosis. ${ }^{4}$ Although응 this is successful in some patients, others rapidly suc- cumb to their disease, suggesting that preoperative $c$ selection of cases with low proliferative rates might substantially improve the results of surgery. In sup $-\vec{c}$ port of this concept Muggia et $a l^{31}$ found that thereo was a correlation between the growth rate of lung. tumours and their response to chemotherapy.

The present study describes a means whereby the treatment of individual lung tumours may be matched to their biological behaviour. The validity of this approach is indicated by the finding that all the $\mathbb{Q}$ small cell carcinomas had high proliferation rates, $\vec{\circ}$ whereas those of the carcinoid tumours were low. 3 This suggests that the selection of cases for chemotherapy on the basis of Ki67 reactivity is likely to be of practical value. Immunocytochemical labelling of histological sections with antibody $\mathrm{Ki67}$ is a simple? technique and well within the scope of routine sur- 3 . gical pathology laboratories. The semiquantitative

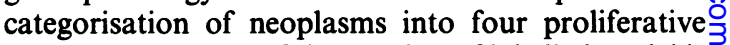
grades on the basis of the number of labelled nuclei is rapidly and reproducibly made by the pathologist; and it represents a very minor addition to the task of $\frac{D}{O}$ histologically categorising individual cases.

The results of the present study confirm that ${ }_{\sigma}$ adenocarcinoma and squamous cell carcinoma of the $\mathrm{N}$ lung vary widely from case to case in their proliferative state. Clinical follow up is necessary to establish $\omega$ whether or not there is a correlation between a lowe proliferative state and long term survival (and vice versa), and this is being undertaken for all the cases in $\Phi$ this study. The gathering of this data and its analysis ${ }^{+}$ will take time, however, and there is an argument for ${ }^{-}$ other centres to collect comparable cases prospec- $\frac{}{\mathbb{N}}$ tively. Showing a correlation between the prolifer- $\frac{\stackrel{\rho}{Q}}{\mathbb{Q}}$ ative state of lung tumours, as determined $\stackrel{\mathbb{Q}}{\square}$ immunocytochemically, and their clinical behaviour 
would have important implications in terms of the treatment of lung cancer, for example, selection of patients for operation or postoperative chemotherapy.

Data from several independent studies will be required if such a correlation is to be proved. It will also be important to try to adapt these techniques for use in preoperative specimens, such as bronchial biopsies or cytological specimens. Finally, the possibility should be noted that immunocytochemical investigation of proliferative rate by the method used in the present study may also prove to be of clinical importance in other types of human neoplasm, such as breast or gastrointestinal cancer.

We are grateful to $\mathrm{Mr} \mathrm{AJ}$ Gunning for providing the surgical specimens and to Lesley Watts for typing the manuscript. This work was supported by the Deutsche Forschungsgemeinschaft and the Wellcome Trust. KCG is a Wellcome senior research fellow and holds the Gillson Scholarship of the Society of Apothecaries of London.

\section{References}

${ }^{1}$ Cohen MH, Matthews MJ. Small cell bronchogenic carcinoma: a distinct clinicopathologic entity. Semin Oncol 1978;5:234-43.

${ }^{2}$ Miller AB, Fox W, Tall R. Five year follow-up of the Medical Research Council comparative trial of surgery and radiotherapy for the primary treatment of small-celled or oat-celled carcinoma of the bronchus. Lancet 1969;ii:501-5.

${ }^{3}$ Vollmer RT, Ogden L, Crissman JD. Separation of small-cell from non-small-cell lung cancer. Arch Pathol Lab Med 1984; 108:792-4.

${ }^{4}$ Mountain CF. Biologic, physiologic, and technical determinants in surgical therapy for lung cancer. In: Straus MJ, ed. Lung cancer: clinical diagnosis and treatment. New York: Grune and Stratton, 1983:245-60.

${ }^{5}$ Broder LH, Cohen MH, Selawry OS. Treatment of bronchogenic carcinoma II. Small cell. Cancer Treat Rev 1977;4:219-60.

${ }^{6}$ Weiss RB. Small cell carcinoma of the lung: therapeutic management. Ann Intern Med 1978;88:522-31.

${ }^{7}$ Willis RA. Epithelial tumours of the trachea, bronchi and lung. In: Pathology of tumours. London: Butterworths, 1948.

${ }^{8}$ Olcott CT. Cell types and histologic patterns in carcinoma of the lung: observations on the significance of tumours containing more than one type of cell. Am J Pathol 1955;31:975-95.

${ }^{9}$ Reid JD, Carr AH. The validity and value of histological and cytological classifications of lung cancer. Cancer 1961;14:673-98.

${ }^{10}$ Hirsch FR, Ottesen G, Podenphant J, Olsen J. Tumor heterogeneity in lung cancer based on light microscopic features. Virchows Arch (Pathol Anat) 1983;402:147-53.

${ }^{11}$ McDowell EM, McLaughlin JS, Merenyi DK, Dieffer RF, Harris CC, Trump BF. The respiratory epithelium V. Histogenesis of lung carcinomas in the human. JNCI 1978;61:587-606.

12 Yesner R, von Hoff DD. Pathologic diagnosis of lung cancer: reappraisal and prospects. In: Muggia F, Rozencweig $M$, eds. Lung cancer: progress in therapeutic research. New York: Raven Press, 1979:175-8.

${ }^{13}$ Mackay B. Ultrastructure of lung neoplasms. In: Straus MJ, ed. Lung cancer: clinical diagnosis and treatment. New York: Grune and Stratton, 1983:85-96.
${ }^{14}$ Dunnili $\overline{\mathrm{M}} \overline{\mathrm{S}}$, Gatter $\overline{\mathrm{K}} \dot{\mathrm{C}}$. Cellular heterogeneity in lung cancer. Histopathology (In press).

${ }^{15}$ Saba SR, Espinoza CG, Richman AV, Azar HA. Carcinomas of the lung: an ultrastructural and immunocytochemical study. Am $J$ Clin Pathol 1983;80:6-13.

${ }^{16}$ Said JW, Nash G, Tepper G, et al. Keratin proteins and carcinoembryonic antigen in lung carcinoma: an immunoperoxidase study of fifty-four cases, with ultrastructural correlations. Hum Pathol 1983;14:70-6.

${ }^{17}$ Gatter KC, Dunnill MS, Pulford KA, Heryet A, Mason DY Human lung tumours: a correlation of antigenic profile with histological type. Histopathology 1985;9:805-23.

${ }^{18}$ Roggli VL, Vollmer RT, Greenberg SD, McGavran MH, Spjut HJ, Yesner R. Lung cancer heterogeneity: a blinded and randomized study of 100 consecutive cases. Hum Pathol 1985; 16:569-79.

${ }^{19} \mathrm{Li}$ WI, Hammar SP, Jolly PC, Hill LD, Anderson RP. Unpredictable course of small cell undifferentiated lung carcinoma. $J$ Thorac Cardiovasc Surg 1981;81:34-43.

${ }^{20}$ Jung-Legg Y, Tomashefski J Jr, Lombard OM, Legg MA. Central small-cell undifferentiated carcinoma of the lung: an analysis of 164 surgically treated patients. Am J Clin Pathol 1984;81:803.

${ }^{21}$ Tomashefski J Jr, Jung-Legg Y, Lombard OM, Legg MA. Peripheral small-cell undifferentiated carcinoma of lung: an analysis of 45 surgically treated patients. Am J Clin Pathol 1984;81:806.

${ }^{22}$ Gerdes J, Schwab U, Lemke H, Stein H. Production of a mouse monoclonal antibody reactive with a human nuclear antigen associated with cell proliferation. Int J Cancer 1983;31:13-20.

${ }^{23}$ Gerdes J, Lemke H, Baisch H, Wacker H-H, Schwab U, Stein H. Cell cycle analysis of a cell proliferation-associated human nuclear antigen defined by the monoclonal antibody $\mathrm{Ki}-67 . J$ Immunol 1984;133:1710-15.

${ }^{24}$ Stein H, Gatter KC, Heryet A, Mason DY. Freeze-dried paraffinembedded human tissue for antigen labelling with monoclonal antibodies. Lancet 1984;ii:71-3.

${ }^{25}$ Stein H, Gatter KC, Asbahr H, Mason DY. Use of freeze-dried paraffin-embedded sections for immunohistologic staining with monoclonal antibodies. Lab Invest 1985;52:676-83.

${ }^{26}$ Cordell JL, Falini B, Erber WN, et al. Immunoenzymatic labeling of monoclonal antibodies using immune complexes of alkaline phosphatase and monoclonal anti-alkaline phosphatase (APAAP complexes). J Histochem Cytochem 1984;32:219-29.

${ }^{27}$ Gatter KC, Falini B, Mason DY. The use of monoclonal antibodies in histopathological diagnosis. In: Anthony PP, MacSween RNM, eds. Recent advances in histopathology. Edinburgh: Churchill Livingstone, 1984:35-67.

${ }^{28}$ Charbit A, Malaise EP, Tubiana M. Relation between the pathological nature and the growth rate of human tumors. Eur $J$ Cancer 1971;7:307-15.

${ }^{29}$ Straus MJ, Moran RE, Shackney SE. Growth characteristics of lung cancer. In: Straus MJ, ed. Lung cancer: clinical diagnosis and treatment. New York: Grune and Stratton, 1983:21-35.

${ }^{30}$ Livingston RB, Ambus U, George SL, Freireich EJ, Hart JS. In vitro determination of thymidine- ${ }^{3} \mathbf{H}$ labeling index in human solid tumors. Cancer Res 1974;34:1376-80.

${ }^{31}$ Muggia FM, Krezoski SK, Hansen HH. Cell kinetic studies in patients with small cell carcinoma of the lung. Cancer 1974;34:1683-90.

${ }^{32}$ Hainau B, Dombernowsky P, Hansen HH, Borgeskov S. Cell proliferation and histologic classification of bronchogenic carcinoma. JNCI 1977;59:1113-8.

Requests for reprints to: Dr KC Gatter, Nuffield Department of Pathology, University of Oxford, John Radcliffe Hospital, Oxford OX3 9DU, England. 